\title{
GROUND-DWELLING SPIDERS IN DIVERSE MOSAIC OF GARDEN HABITATS
}

\author{
KRUMPÁlovÁ, Z..$^{1 *}$ - ONDREJKOVÁ, N. ${ }^{1}$ - IVANIČ-PORHAJAŠOVÁ, J. ${ }^{2}$ - PETROVIČOVÁ, K. ${ }^{2}$ - \\ LANGRAF, V. ${ }^{3}$ \\ ${ }^{1}$ Department of Ecology and Environmental Sciences, Faculty of Natural Sciences, Constantine \\ the Philosopher University, Nitra, Slovakia \\ ${ }^{2}$ Department of Environment and Biology, Faculty of Agrobiology and food resources, Slovak \\ University of Agriculture, Nitra, Slovakia \\ ${ }^{3}$ Department of Zoology and Anthropology, Faculty of Natural Sciences, Constantine the \\ Philosopher University, Nitra, Slovakia \\ ${ }^{*}$ Corresponding author \\ e-mail: zkrumpalova@ukf.sk; phone: +421-917-201-036 \\ (Received $17^{\text {th }}$ Nov 2020; accepted $3^{\text {rd }}$ Mar 2021)
}

\begin{abstract}
The species composition of a biota in an urban environment can greatly depend on the characteristics of local and surrounding habitats. Research on the composition of spider communities was carried out in a private garden, in various places - stored wood, under thujas, on a mown lawn, in an orchard and in a garden with crops, to identify habitat variables associated with fluctuations in spider assemblages affected by human disturbance. Although gardens do not seem to be as diverse as the natural places, we found a surprisingly large variety of spiders, 74 species. Differences in the composition of spider communities between land use types were - a small number of species tolerant to the urban environment, a high number of specific species that showed different responses to habitat properties such as vegetation cover, light and humidity conditions and human activity. We found interesting records of new species that were spread by humans - species successfully adapted to synanthropic environments. In gardens, our records were the second one to report adult individuals of Hoplopholcus forskali and Mermessus trilobatus, so far found as juveniles in botanical gardens or Tallusia vindobonensis, previously only found in salt marshes. Tegenaria hasperi is a new spider to Slovakia.

Keywords: urban environment, invertebrates, biodiversity, urban green space, human influence, bioindication, private garden
\end{abstract}

\section{Introduction}

Urban gardens are a major component of urban green spaces in many countries (Loram et al., 2008; Edmondson et al., 2014). They are heterogeneous in structure, but despite their relatively small size they provide critical habitat resources and increase the connectivity of urban landscapes (Soanes, 2019). Urban gardens are popular green spaces that have the potential to provide essential ecosystem services, support human well-being, and at the same time foster biodiversity in cities (Tresch et al., 2019).

The garden is an important refuge for biota in an urban environment. It forms a diverse mosaic of interesting habitats, where man creates an important, structured and relatively diverse ecosystem. It is a space for a specific fauna of invertebrates. Gardens form separate micro-ecosystems with typical conditions, they are not only completely man-made, but also disturbed and altered. They are a special type of habitat, absolutely different from the surrounding nature, with the characteristic planting of non-native transported trees, plants and soil. On the one hand, some gardens are built with usefulness in mind, planting of agricultural crops and fruit trees (they are regularly 
disturbed - hoeing, selective watering, fertilization, loosening, weeding, they have a very short growing season, etc.); others are recreational-type gardens - with exotic trees and sown lawn, often without flowering plants (they are regularly disturbed by grass mowing, watering, fertilization and loosening; in the case of trees and trusses - pruning and crown formation, etc.) (Ondrejková and Purgat, 2019; Krumpálová et al., 2020b).

Spiders as suitable model animals provide us with important information about the environment in which we find them. Spiders, especially ground dwelling, are considered an important bioindication group. In connection with human activities, they react very sensitively to changes in the country (Rüžčka, 1987). In general, the decrease in spiders per unit area depends on the difference between the original state and the current one. This reflects the degree of anthropogenic influence on the habitat (Růžička, 1987). The spider may, for example, assess a microhabitat as a potential web site, oviposition site, overwintering site or as a safe haven from predators during the inactive phase of a diel cycle. Spider may need to seek temporary refuge in a favourable micro-habitat in order to maintain its physiological integrity. From this it follows that individuals of any spider population are harboured by specific micro-habitats which might vary over time, according to the current needs of the individuals (Samu et al., 1999). Selection of micro-habitat by individual spiders is likely to be in relation to a specific biological need or collection of needs or may reflect avoidance of some factor, such as interspecific encounters (Post and Riechert, 1977). Soil organisms are sensitive to environmental contamination, in which they occur and also called stress as bioindicators. Their reaction may result to the environmental load in different ways - in a change in behaviour; a change in habitat; a quantitative change and composition of species spectrum; and into physiological or morphological deformation of the individual or of the whole community (Baranová et al., 2015). The soil edaphon is an important component of biocoenosis, reflects the burden on biotopes and is an important bioindicator of environmental quality (Porhajašová-Ivanič et al., 2016).

In Slovakia, the research of invertebrates in gardens has not yet received much attention. Invertebrates' investigation in this environment is pioneering. Spiders were part of the study of the urban environment in the region of Nitra (Ondrejková and Purgat, 2019; Krumpálová et al., 2020a,b; Purgat et al., 2020), the authors concluded that some of them have adapted on urban conditions and occupy habitats with high human influence: Lycosa singoriensis on mowed lawns, Allagelena gracilens on modified shrubs, Brigittea civica and Larinioides ixobolus on walls of buildings. On the contrary, the progressive ruderalisation of the peripheral parts of the towns and the low anthropic influence create suitable habitats for Cheiracanthium punctorium. Attention was also paid to soil mites (Oribatida) in planted garden (Krumpálová et al., 2020b). In Hungary, Magura et al. (2010) studied the effects of urbanization on ground-dwelling spiders (Araneae) along an urban-suburban-rural forest gradient in Debrecen, and found that overall spider species richness was significantly higher in the urban sites compared to the suburban and rural ones. Tajthi et al. (2017) assumed a higher number of species in suburban habitats than in rural or urban ones, where they also confirmed the hypothesis of species susceptibility to disturbance. In Denmark, fragments of the suburban, rural and urban forest were observed by Horváth et al. (2014), so the highest number of common species was in suburban and urban habitats. Research shows that urbanization did not reduce biodiversity, but there were few common species with native forest habitats. Lowe et al. (2017) compared araneocenoses in private gardens, city parks and residual vegetation. The gardens excelled in relatively high diversity. 
Coenoses differed significantly between gardens and other urban areas. In Finland, Alaruikka et al. (2002) confirmed the significant influence of the locality, while spiders were affected on a small scale by the structure of the habitat itself; large urban areas had a greater influence.

We hypothesised that i. - intensive soil management will reduce the species diversity in garden; ii. - a higher diversity of plants will have a positive effect on higher diversity of spiders than in recreational garden; iii. - the gardens create conditions and offer space for specific species little known from the natural environment.

The aim of this study was to analyze the coenoses of spiders in different five microhabitats of the garden, we expected that frequently disturbed places would have the lowest species diversity within (alpha diversity) and among (beta diversity) garden sites. Additionally, we tried to find differences between garden land-use types in analyzing of species diversity, and evaluate the data obtained as a whole with a view to emphasizing the importance of gardens in the urban environment.

\section{Material and methods}

This study took place in private garden of family houses of the village Machulince (Nitra region); $48^{\circ} 24^{\prime} \mathrm{N}, 18^{\circ} 25^{\prime} \mathrm{E}$; in western part of Slovakia in the Danubian lowland.

We chose the garden, in the area of $880 \mathrm{~m}^{2}$, and on the basis of two independent criteria: i. the recreational part of the garden and ii. garden with cultivated crops and old orchard. In the recreational garden, three sampling plots (2 traps in each plot) with different land management were selected. The first place was in the part of the garden with stored wood, shaded during the year and least affected by human influences; the second place was an artificially planted shrub vegetation of non-native trees (Thuja occidentalis) with minimal interference; and the third place was on an open artificially planted lawn, where the interventions in the form of irrigation, regular mowing and raking took place during the year. In the managed part of the garden with cultivated crops, two sampling plots (2 traps in each place) were selected - a study place in the orchard, where the original, sporadically mowed lawn was partially shaded by tree vegetation and the fifth study place was located in a cultivated garden with crops, in which the greatest human interventions and disturbances were present (plowing, planting, selective irrigation and fertilization) and vegetation cover occurred only during the active period of cultivated crops, in the remaining time only the soil was without vegetation. The distance between the sampling plots was about 30 metres.

Spiders were collected in each of the 5 places using traps. There were two traps at each studied microhabitat, approximately $3 \mathrm{~m}$ apart. Pitfall traps (glass cups; $6.5 \mathrm{~cm}$ in diameter) were filled with a fixative, a formaldehyde solution. Traps were exposed continuously throughout the year, from September 2017 to October 2018. Trapped spiders were picked up every month.

Collected individuals were identified by using the works of Heimer and Nentwig (1991), Miller (1971), or www.arachno.piwigo.com and Nentwig et al. (2020) www.araneae.nmbe.ch. Juvenile and sub adult stages were determined at the genus level. Nomenclature followed the World Spider Catalog (2020). Habitat affinity, ecological demands of spiders (humidity or light requirements) of the collected species was designated from the literature (Buchar and Růžička, 2002). 


\section{Statistical analyses}

The analyses in the PAST-software, version 2.14 (Hammer et al., 2001) and Statistica, version 7 (2004) was focused on quantitative-qualitative methods. By Shapiro-Wilks W-test we tested the normality of data distribution of number of individuals and species of the spiders. Kruskal-Wallis test (ANOVA) we used to test the differences in number of individuals and species between microhabitats. Cluster analysis (Bray-Curtis index) in the algorithm (UPGMA) we found a similarity of spider assemblages. Spatial modeling was performed by multivariate analysis in the program Canoco 5 (Ter Braak and Šmilauer, 2012), with which we look for dependencies between objects species of spiders and biotopes (wood, thuja, lawn, orchard, garden with crops). We used Principal Component Analysis (PCA) to evaluate the dependence and similarity between studied coenoses.

\section{Results}

\section{Habitats with a high diversity of spiders}

The total spider catch consisted of 536 individuals representing 74 species (99 taxa, resp.) (Table 1). Many or most of species were found singletons and doubletons. Erigone dentipalpis, Pardosa hortensis and juveniles from genus Pardosa were dominant. Diversity indices of all collected garden spiders achieved a very high values Shannon $\mathrm{H}^{\prime}=3.99$, Margalef $=15.74$ and Pielou $=0.86$ (Table 2).

In the stored wood there were 105 individuals belonging to 43 species, under thujas we found higher number of individuals (124) and species (44), whereas in mowed lawn we collected 84 individuals of 30 species, in orchard were 116 individuals belonging to 31 species, and in garden with crops 107 individuals representing 26 species were captured (Table 1).

The normality data distribution (number of individuals) was violation ( $\mathrm{p}$-value $=0.00)$, based on we are used a nonparametric Kruskal-Wallis test (ANOVA) to confirm the statistically non-significant difference $(\mathrm{p}$-value $=0.3112)$ between spider assemblages in microhabitats (Fig. 1). Number of individuals in the garden as a whole was relatively balanced; but the number of species in the coenoses varied and had significant differences (Fig. 2).

The normality data distribution (number of species) was violation ( $\mathrm{p}$-value $=0.01$ ), based on we are used a nonparametric Kruskal-Wallis test (ANOVA) to confirm the statistically significant difference ( $\mathrm{p}$-value $=0.0131$ ) between biotopes (Fig. 2). Most of the species were found under thujas and stored wood, lower number was in mowed lawn and orchard, and the lowest number of species was in the garden with crops.

\section{Garden micro-habitats offer different living condition}

In the recreational part of the garden with planted thujas, forming a barrier from the surroundings and stored wood, study site was characterized by small disturbing influence of humans, there were relatively low soil humidity and high shading, and there was no vegetation cover. Despite the fact, it was found that spider communities differ not only from the other three habitats, but these two habitats were dissimilar to each other in species composition and assemblages structure (Figures 2-4). 
Table 1. Abundance of spiders in different habitats of the gardens

\begin{tabular}{|c|c|c|c|c|c|c|c|}
\hline Taxon - species/ study site & $\begin{array}{l}\text { stored } \\
\text { wood }\end{array}$ & thujas & $\begin{array}{c}\text { mowed } \\
\text { lawn }\end{array}$ & orchard & \begin{tabular}{|c|} 
garden \\
with \\
crops \\
\end{tabular} & $\sum$ & $\begin{array}{c}\text { Total } \\
\text { dominance }(\%)\end{array}$ \\
\hline Scytotidae & & & & & & & \\
\hline Scytodes thoracica (Latreille, 1802) & 1 & & 1 & & & 2 & 0.4 \\
\hline Pholcidae & & & & & & & \\
\hline Hoplopholcus forskali (Thorell, 1871) & 11 & & & & & 11 & 2.1 \\
\hline Pholcus opilionides (Schrank, 1781) & 2 & 17 & 4 & & & 23 & 4.3 \\
\hline Pholcus sp. & & 6 & & & & 6 & 1.1 \\
\hline Dysderidae & & & & & & & \\
\hline Dysdera sp. & 1 & & & & & 1 & 0.2 \\
\hline Harpactea rubicunda (C. L. Koch, 1838) & 5 & 3 & & & & 8 & 1.5 \\
\hline Harpactea sp. & 2 & 1 & & & & 3 & 0.6 \\
\hline Mimetidae & & & & & & & \\
\hline Ero furcata (Villers, 1789) & 1 & & & & & 1 & 0.2 \\
\hline Ero tuberculata (De Geer, 177) & & 1 & & & & 1 & 0.2 \\
\hline Theridiidae & & & & & & & \\
\hline Asagena phalerata (Panzer, 1801) & & & 6 & & 2 & 8 & 1.5 \\
\hline Euryopis sp. & & & & 1 & & 1 & 0.2 \\
\hline Lasaeola tristis (Hahn, 1833) & & & & 1 & & 1 & 0.2 \\
\hline Robertus arundineti (O. P. Cambridge, 1871) & & 1 & & & & 1 & 0.2 \\
\hline Robertus lividus (Blackwall, 1836) & 4 & 1 & & & & 5 & 0.9 \\
\hline Steatoda $\mathrm{sp}$ & 3 & 0 & & 1 & & 4 & 0.7 \\
\hline Linyphiidae & & & & & & & \\
\hline Agyneta cauta (P. O. Cambridge, 1902) & & & 7 & 2 & 2 & 11 & 2.1 \\
\hline Araeoncus humilis (Blackwall, 1841) & & & 1 & & & 1 & 0.2 \\
\hline Centromerus sp. & & & 2 & & & 2 & 0.4 \\
\hline Centromerus sylvaticus (Blackwall, 1841) & 1 & 3 & & 2 & & 6 & 1.1 \\
\hline Diplostyla concolor (Wider, 1834) & 3 & 9 & 1 & & & 13 & 2.4 \\
\hline Erigone dentipalpis (Wider, 1834) & & & 8 & 26 & 10 & 44 & 8.2 \\
\hline Leptyphantes angulatus (P. O. Cambr., 1881) & 1 & & & & & 1 & 0.2 \\
\hline Leptyphantes leprosus (Ohlert, 1865) & 1 & & & & & 1 & 0.2 \\
\hline Leptyphantes sp. & 7 & 2 & & & 3 & 12 & 2.2 \\
\hline Leptyphantes tenuis (Blackwall, 1852) & 1 & 1 & & & & 2 & 0.4 \\
\hline Mermessus trilobatus (Emerton, 1882) & 3 & 6 & 2 & & 2 & 13 & 2.4 \\
\hline Micrargus subaequalis (Westring, 1851) & & 3 & & & & 3 & 0.6 \\
\hline Oedothorax apicatus (Blackwall, 1850) & & & & 7 & 4 & 11 & 2.1 \\
\hline Oedothorax sp. & & & & 1 & & 1 & 0.2 \\
\hline Palliduphantes pallidus (P. O. Cambr., 1871) & & & & & 1 & 1 & 0.2 \\
\hline Porrhoma sp. & & & & 1 & & 1 & 0.2 \\
\hline Porrhoma campbelli (F. O. P.-Cambr., 1894) & 2 & 1 & & & & 3 & 0.6 \\
\hline Porrhoma pygmaeum (Blackwall, 1834) & & 1 & & & & 1 & 0.2 \\
\hline Sintula $\mathrm{sp}$ & & 1 & & & & 1 & 0.2 \\
\hline Stemonyphantes lineatus (Linné, 1758) & & 4 & & & 1 & 5 & 0.9 \\
\hline Tallusia vindobonensis (Kluczyński, 1898) & & 1 & 1 & & & 2 & 0.4 \\
\hline Tapinocyba biscissa (P. O.-Cambridge, 1872) & 1 & & & & & 1 & 0.2 \\
\hline Trematocephalus cristatus (Wider, 1834) & & 3 & & & & 3 & 0.6 \\
\hline Trichopterna cito (P. O.-Cambridge, 1872) & & & & 4 & & 4 & 0.7 \\
\hline Walckenaria capito (Westring, 1861) & 1 & 3 & & & & 4 & 0.7 \\
\hline Tetragnathidae & & & & & & & \\
\hline Pachygnatha degeeri (Sundevall, 1830) & & & & 4 & & 4 & 0.7 \\
\hline Araneidae & & & & & & & \\
\hline Araniela sp. & & & & 1 & & 1 & 0.2 \\
\hline
\end{tabular}




\begin{tabular}{|c|c|c|c|c|c|c|c|}
\hline Taxon - species/ study site & $\begin{array}{l}\text { stored } \\
\text { wood }\end{array}$ & thujas & $\begin{array}{c}\text { mowed } \\
\text { lawn }\end{array}$ & orchard & \begin{tabular}{|c} 
garden \\
with \\
crops \\
\end{tabular} & $\sum$ & $\begin{array}{c}\text { Total } \\
\text { dominance }(\%)\end{array}$ \\
\hline Lycosiadae & & & & & & & \\
\hline Alopecosa pulverulenta (Clerck, 1757) & 1 & & & & & 1 & 0.2 \\
\hline Alopecosa sp. & 3 & 4 & 3 & 1 & & 11 & 2.1 \\
\hline Arctosa sp. & & & 2 & & & 2 & 0.4 \\
\hline Aulonia albimana (Walckenaer, 1805) & 2 & & & & & 2 & 0.4 \\
\hline Pardosa agrestis (Westring, 1861) & 1 & 1 & 2 & 1 & & 5 & 0.9 \\
\hline Pardosa agricola (Thorell, 1856) & & & & 2 & & 2 & 0.4 \\
\hline Pardosa bifasciata (C. L. Koch, 1834) & & 1 & & & & 1 & 0.2 \\
\hline Pardosa hortensis (Thorell, 1872) & 4 & & & 7 & 19 & 30 & 5.6 \\
\hline Pardosa lugubris (Walckenaer, 1802) & 1 & & & & & 1 & 0.2 \\
\hline Pardosa monticola (Clerck, 1757) & & & 1 & 1 & 2 & 4 & 0.7 \\
\hline Pardosa palustris (Linné, 1758) & & & 4 & & 1 & 5 & 0.9 \\
\hline Pardosa prativaga (L. Koch 1870$)$ & & 1 & & 1 & & 2 & 0.4 \\
\hline Pardosa pullata (Clerck, 1757) & & & & & 1 & 1 & 0.2 \\
\hline Pardosa sp. & 15 & 8 & 8 & 14 & 5 & 50 & 9.3 \\
\hline Trochosa robusta (Simon, 1876) & 1 & & 2 & & 2 & 5 & 0.9 \\
\hline Trochosa ruricola (Simon, 1876) & & 1 & & 3 & & 4 & 0.7 \\
\hline Trochosa sp. & & & 1 & 1 & & 2 & 0.4 \\
\hline Xerolycosa miniata (C. L. Koch, 1834) & & & & 4 & 12 & 16 & 3.0 \\
\hline Xerolycosa nemoralis (Westring. 1861) & & & & & 10 & 10 & 1.9 \\
\hline Xerolycosa sp. & & & 1 & & & 1 & 0.2 \\
\hline $\begin{array}{l}\text { Pisauridae } \\
\end{array}$ & & & & & & & \\
\hline Pisaura mirabilis (Clerck, 1757) & & 1 & & & & 1 & 0.2 \\
\hline Agelenidae & & & & & & & \\
\hline Agelena gracilens (C. L. Koch, 1841) & 1 & 5 & & & & 6 & 1.1 \\
\hline Agelena sp. & & 3 & 4 & & & 7 & 1.3 \\
\hline Coelotes sp. & & 1 & & & & 1 & 0.2 \\
\hline Eratigena agrestis (Walckenaer, 1802) & & & 2 & & & 2 & 0.4 \\
\hline Tegenaria domestica (Clerck, 1757) & 1 & & & & & 1 & 0.2 \\
\hline Tegenaria hasperi (Chyzer, 1897) & 1 & & & 1 & & 2 & 0.4 \\
\hline Tegenaria sp. & 1 & & & & & 1 & 0.2 \\
\hline Urocoras longispina (Kulczyński, 1897) & 5 & & & & & 5 & 0.9 \\
\hline Hahniidae & & & & & & & \\
\hline Hahnia helveola (Simon,1875) & & & 4 & & & 4 & 0.7 \\
\hline Hahnia nava (Blackwall, 1841) & & 2 & & & 2 & 4 & 0.7 \\
\hline Hahnia pusilla (C. L. Koch, 1841) & 1 & 1 & 1 & 3 & & 6 & 1.1 \\
\hline Cicurina cicur (Fabricius, 1793) & 1 & & & & & 1 & 0.2 \\
\hline Amaurobiidae & & & & & & & \\
\hline Amarobius ferox (Walckenaer, 1830) & & 1 & & & & 1 & 0.2 \\
\hline Liocranidae & & & & & & & \\
\hline Liocranoeca $\mathrm{sp}$ & & & 1 & & & 1 & 0.2 \\
\hline Sagana rutilans (Thorell, 1875) & 4 & & & & & 4 & 0.7 \\
\hline Clubionidae & & & & & & & \\
\hline $\begin{array}{l}\text { Clubiona sp. } \\
\text { Zodariidae }\end{array}$ & 1 & 1 & & & & 2 & 0.4 \\
\hline Zodarion rubidum (Simon, 1914) & & 2 & & 5 & 9 & 16 & 3.0 \\
\hline Gnaphosidae & & & & & & & \\
\hline Civizelotes gracilis (Canestrini, 1868) & & 1 & 1 & 7 & 7 & 16 & 3.0 \\
\hline Drassodes lapidosus (Walckenaer, 1802) & & 2 & 5 & & & 7 & 1.3 \\
\hline Drassodes sp. & & & 2 & & 2 & 4 & 0.7 \\
\hline Drassyllus pumilus (C. L. Koch, 1833) & & 1 & & & 4 & 5 & 0.9 \\
\hline Drassyllus pusillus (C. L. Koch 1833) & & & & 6 & 2 & 8 & 1.5 \\
\hline Drassyllus sp. & 2 & 10 & & & & 12 & 2.2 \\
\hline
\end{tabular}




\begin{tabular}{|c|c|c|c|c|c|c|c|}
\hline Taxon - species/ study site & $\begin{array}{l}\text { stored } \\
\text { wood }\end{array}$ & thujas & $\underset{\text { mowed }}{\text { lawn }}$ & orchard & $\begin{array}{l}\text { garden } \\
\text { with } \\
\text { crops }\end{array}$ & $\sum$ & $\begin{array}{c}\text { Total } \\
\text { dominance }(\%)\end{array}$ \\
\hline Drassyllus villicus (Thorell, 1875) & 1 & 1 & & & & 2 & 0.4 \\
\hline Drassylus pareficus (L. Koch, 1866) & & 1 & & & & 1 & 0.2 \\
\hline Haplodrassus signifer (C. L. Koch, 1839) & 2 & & & & & 2 & 0.4 \\
\hline Trachyzelotes pedestris (C. L. Koch, 1837) & & 2 & & & 1 & 3 & 0.6 \\
\hline Zelotes apricorum (C. L. Koch, 1876) & 2 & & & & & 2 & 0.4 \\
\hline Zelotes electus (C. L. Koch, 1839) & 1 & & & & & 1 & 0.2 \\
\hline $\begin{array}{c}\text { Zelotes sp. } \\
\text { Zoridae }\end{array}$ & & 4 & 5 & 5 & 1 & 15 & 2.8 \\
\hline Zora silvestris (Kulczyński, 1897) & 1 & & & & & 1 & 0.2 \\
\hline Thomisidae & & & & & & & \\
\hline Diaea dorsata (Fabricius, 1777) & & & & & 1 & 1 & 0.2 \\
\hline Xysticus erraticus (Blackwall, 1834) & & & 1 & & & 1 & 0.2 \\
\hline Xysticus kochi (Thorell, 1872) & & & 1 & 1 & & 2 & 0.4 \\
\hline $\begin{array}{c}\text { Xysticus sp. } \\
\text { Salticidae }\end{array}$ & 1 & & & 1 & & 2 & 0.4 \\
\hline Phlegra fasciata (Hahn, 1826) & & 1 & & 1 & 1 & 3 & 0.6 \\
\hline Total number of individuals & 105 & 124 & 84 & 116 & 107 & 536 & \\
\hline
\end{tabular}

Table 2. Diversity indices of spider assemblages in garden

\begin{tabular}{c|c|c|c|c|c|c}
\hline & wood & thuja & lawn & orchard & crop garden & $\begin{array}{c}\text { Whole } \\
\text { garden }\end{array}$ \\
\hline Taxa_S & 43 & 44 & 30 & 31 & 26 & 99 \\
Individuals & 105 & 124 & 84 & 116 & 107 & 536 \\
Shannon (H') & 3.36 & 3.37 & 3.13 & 2.89 & 2.82 & 3.99 \\
Margalef (R) & 9.03 & 8.92 & 6.55 & 6.31 & 5.35 & 15.74 \\
Equitability (e) & 0.89 & 0.89 & 0.92 & 0.84 & 0.86 & 0.86 \\
\hline
\end{tabular}

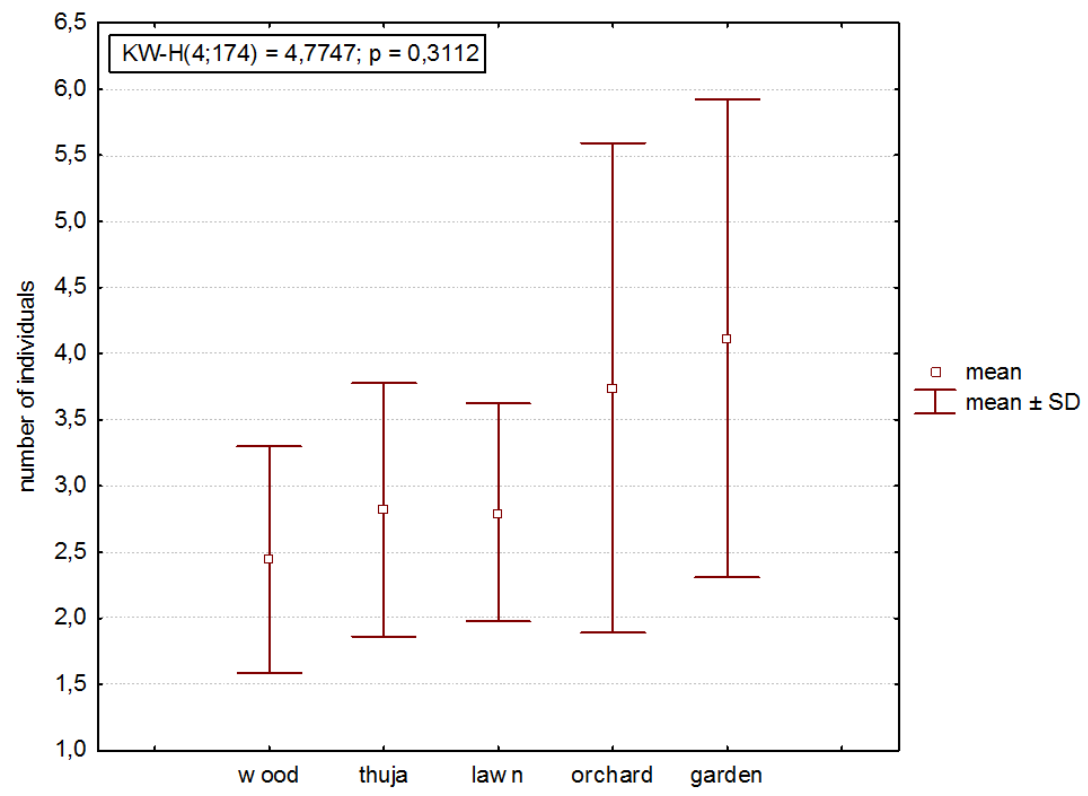

Figure 1. Kruskal-Wallis test (ANOVA) of abundance among the spider communities in the microhabitats of garden 


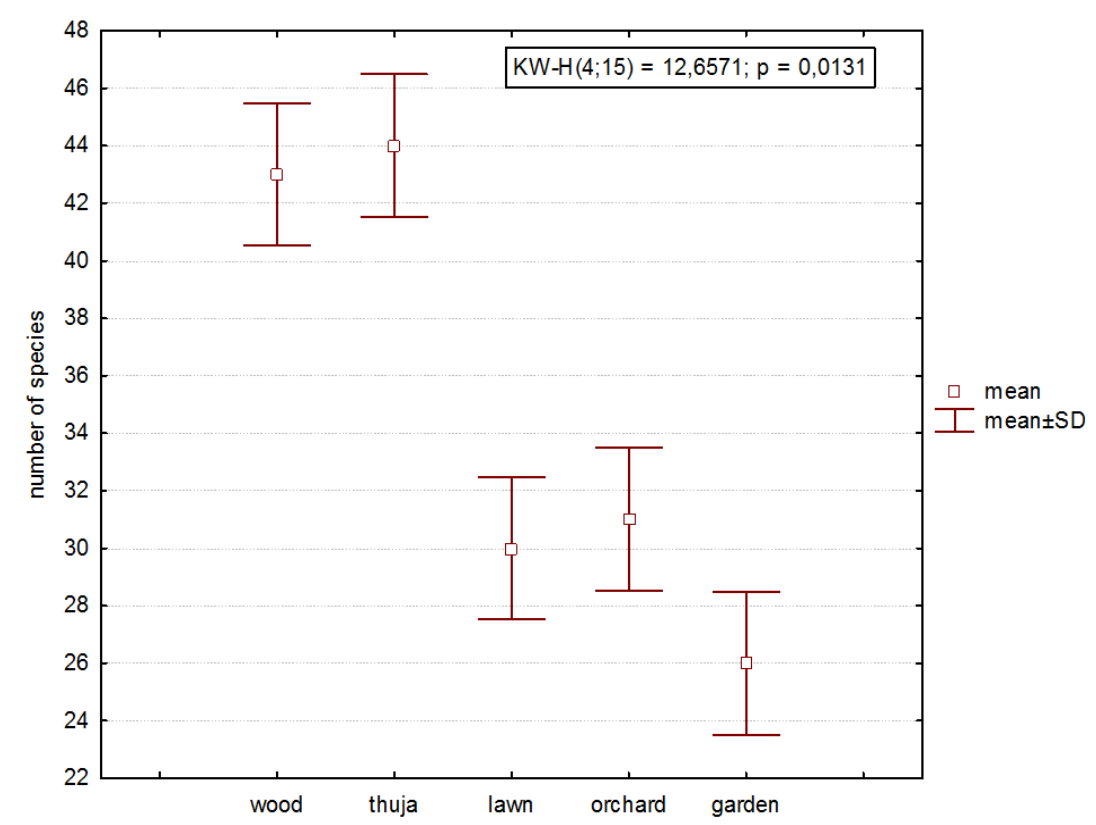

Figure 2. Kruskal-Wallis test (ANOVA) of spider species spectrum in the garden microhabitats

In the study site - stored wood we collected 105 individuals belonging to 43 species. Diversity indices were high $\left(\mathrm{H}^{\prime}=3.36\right)$, as well as species richness $(\mathrm{R}=9.03)$ and equitability (e = 0.89) (Tables 1 and 2). H. forskali, H. rubicunda, U. longispina and juveniles from the genus Lepthyphantes (sensu lato) and Pardosa were dominant.

In the thujas site - was the spider assemblages the richest as in the number of individuals (124) as in the number of species (44). P. opilionides, E. dentipalpis, D. concolor, M. trilobatus and juveniles from the genus Pardosa and Drassyllus dominated there. Diversity, species richness and equitability were high at this study site (Tables 1 and 2).

Next study plots were grasslands, in which the human disturbance was higher. Mowed lawn in the recreational part of garden was regularly watered and maintained. In the recreational lawn we found 84 individuals only, belonging to 30 species. We noticed a co-dominance of $A$. phalerata, A. cauta, L. angulatus, P. palustris, $H$. helveola, D. lapidosus and juveniles from the gen. Zelotes, Agelena, Pholcus and Pardosa here; so the spiders' community in the lawn reached the highest equitability. This spider coenose in garden was absolutely dissimilar to others (Figures 3 and 4).

Second studied lawn in orchard was in the cultivated part of garden, but it was rarely taken care of, there were lower human intervention. In the grassland of orchard, we trapped 116 individuals belonging to 31 species (Tables 1 and 2), in which E. dentipalpis highly predominated; O. apicatus, P. hortensis, C. gracilis, D. pusillus and non-adults from the genus Pardosa were dominant spiders there.

Study site - the cultivated garden with planted crops was subject with the highest human disturbance all year round, in the form of loosening the soil, selective watering and early end of the growing season (after harvesting of the crops we did not collected any spiders there). All these facts resulted in lower number of species (26); there were the lowest values of diversity indices from all monitored communities of gardens (Tables 1 and 2). P. hortensis predominate at this study site, next species E. dentipalpis, $X$. miniata, $X$. nemoralis, $Z$. rubidum and $C$. gracilis were dominants. 


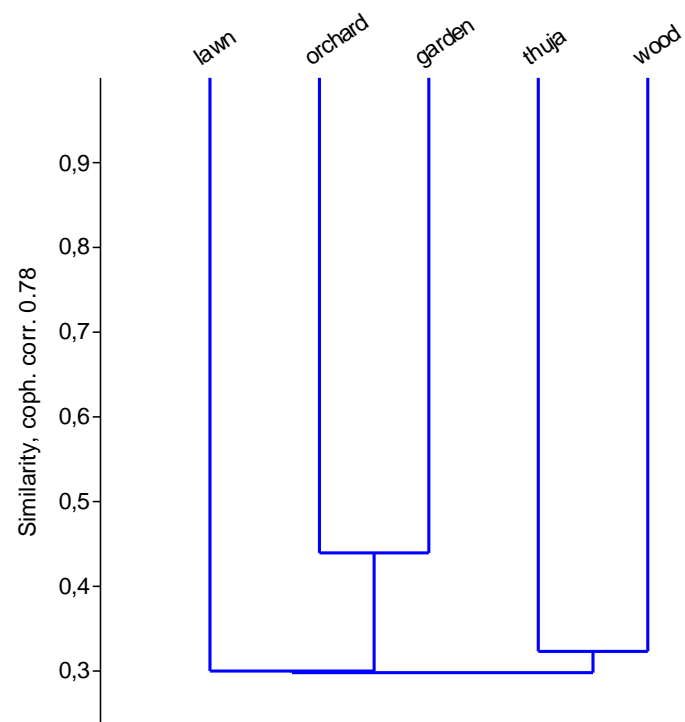

Figure 3. Similarity of spider communities at five different microhabitats in garden (single linkage cluster analysis, Bray-Curtis)

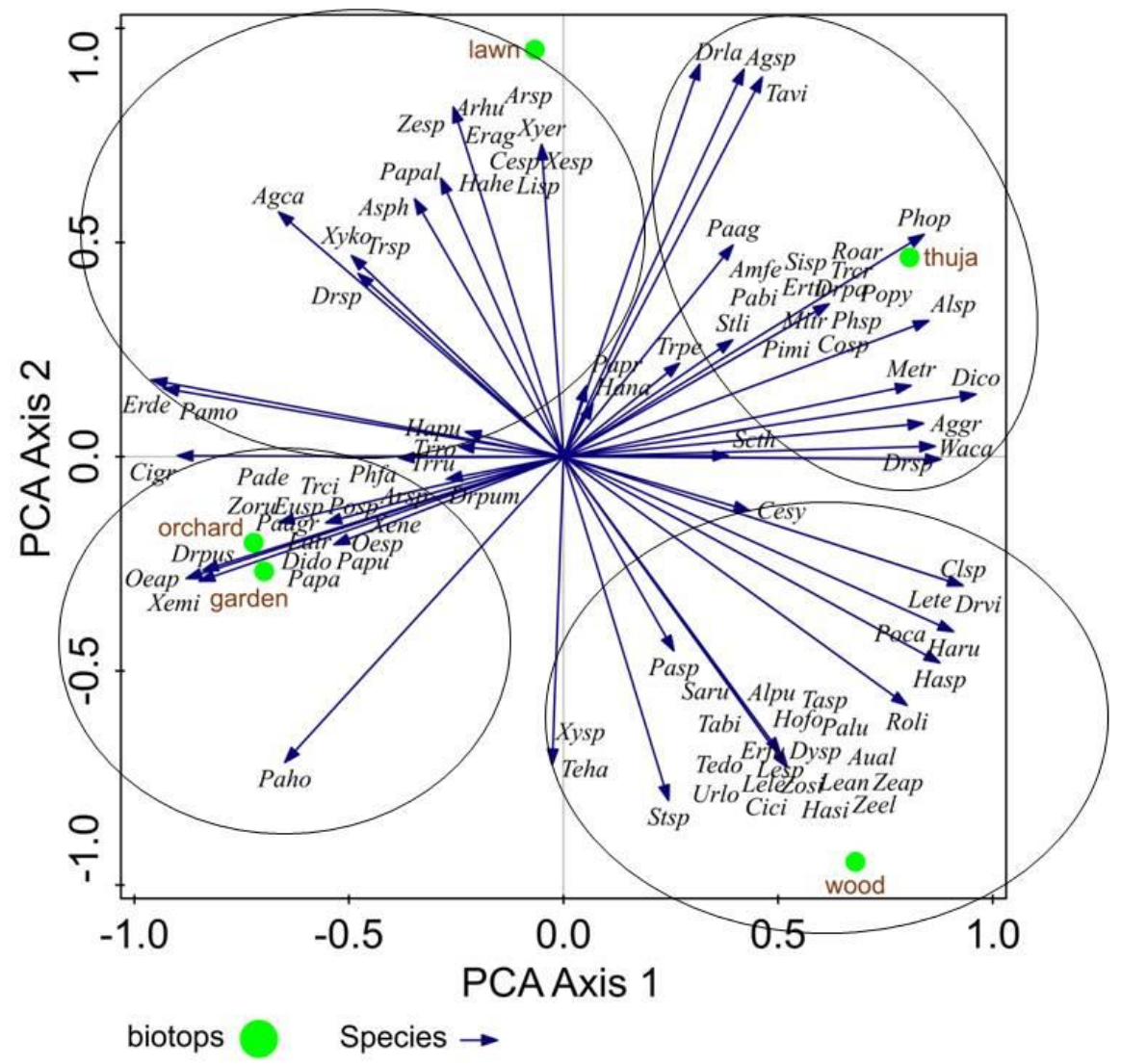

Figure 4. PCA analysis of species distribution in the five different study sites of garden

Cluster analysis revealed that the spider assemblages of garden habitats (single linkage cluster analysis, Bray-Curtis) were dissimilar (Figure 3; similarity level 0.3). A separate branch was created by two coenoses of dry and shaded habitats of the garden, 
under thujas and wood storage. Separate line represents the coenose of mowed lawn in recreational part of garden. Spiders in orchard and garden with crops, which preferred higher growth of plants, create more similar group.

If we evaluate the spiders of the garden as a whole, we can state that species with high demands on light conditions (direct light) accounted for $42 \%$, with the largest number being in the garden with crops. The number of spiders with shading requirement the habitat was almost the same (41\%), most of sciophilous individuals gathered in the recreational part of the garden, on the mown lawn, under wood and thujas. The demands of the spiders in terms of humidity conditions were as follows xerophilous (42\%), hemixerophilous (14\%) and hemihygrophilous - 20\%; while most xerophilous individuals were in the garden with crops, spiders with higher requirements on moisture were in the grassland of orchard.

\section{Impact of human activities vs. specific micro-habitats in garden}

Multivariate analysis of spiders at five garden micro-habitats was determined by Principal Component Analysis (PCA, $\mathrm{SD}=3$ was on the first ordination axis). The values of the explained cumulative variability of species data were $43.79 \%$ on the $1^{\text {st }}$ ordination axis and $67.51 \%$ on the $2^{\text {nd }}$ ordination axis. The ordination graph (biplot) contains species ordered into four clusters (Fig. 4).

Spider assemblages were characterized by certain number of specific spiders, which were found in the certain habitats, only. Under the wood we found 19 specific species, occurred only in this place; under thujas we recorded 12 specific spider species. Spider assemblages in moved lawn and orchard had 8 specific species each (Table 1). The lowest specific species that would characterize the habitat a microclimatic condition, we found in the garden with crops, four only. The garden as the urban environment is a space altered by anthropic activities with varying degrees of disturbance. Due to the highest human interventions in garden with crops, orchard or on the moved lawn we found there a lower species spectrum and lower number of specific spiders. While in undisturbed places (under thuja and stored wood) we found many specific species and the diversity was higher (Figs. 2 and 4). We can conclude that on a relatively small gardens' area there was a diverse mosaic of micro-habitats have created suitable conditions for different types of arachnocoenoses, but these assemblages have been strongly influenced by human activities. The gardens seem to be quite an interesting space for the existence of many spiders with different requirements for a successful life.

\section{Conditions and places for adaptation of a new spider species}

Gardens seem to be an appropriate habitat (small place with many microclimatic conditions) for colonisation by aliens or newly established species. Here we found the adult spider individuals of both sexes, so far found as juveniles only in botanical garden. Significant research results include the findings of the following species - Tallusia vindobonensis (Kulczyński, 1898), we found two males under the thujas and in the lawn, this is a second record for Slovakia. Gajdoš et al. (2019) found this species in Pannonic salt marshes. Next interesting species was Hoplopholcus forskali (Thorell, 1871) - juveniles we collected in the interior of the house, males and females under thujas; this is the second record for Slovakia (so far juveniles were only found in the botanical garden). Males of Mermessus trilobatus (Emerton, 1882) we found under thujas; it is a second record for Slovakia (it was found only in the botanical garden by Šestáková et al. 2017), this North American species spreads to Central Europe via 
Germany. The first record for Slovak fauna was Tegenaria hasperi (Chyzer, 1897) from the family Gnaphosidae, males of which we collected under thujas (males were after mating).

Gardens can create very suitable conditions for the adaptation of non-original, resp. alien spider species as well. In studied garden we found a very high diversity, interesting records of species or spiders successfully adapted to urban conditions.

\section{Discussion}

Urban gardens are popular green spaces that have the potential to provide essential ecosystem services, support human well-being, and at the same time foster biodiversity in cities (Tresch et al., 2019). As species have different responses to anthropogenic habitat modification, the species composition of urban areas can depend greatly on the habitat characteristics of the local and surrounding areas (Lowe et al., 2017). We suppose the results of our study of the private gardens with five various micro-habitats are original and indicate creation the appropriate conditions for a high diversity of ground-dwelling spiders; we found there nearly one hundred of taxa. Species composition differed significantly between garden micro-habitats. The higher spider species diversity of gardens was also associated with specific soil cover (thujas, stored wood) as well as with lower disturbance on these study sites (orchard, thujas and wood), which suggests that local management had an impact on biodiversity. In contrast, Lowe et al. (2017) concluded that gardens are not as diverse as the surrounding vegetation areas with increased vegetation cover.

This study shows that using urban land in the form of private gardens support unique spider communities and the maintenance of this form of management in the urban matrix, it is necessary to support it in the cities. Differences in the composition of communities between types of land use have been caused by a small number of tolerant spider species, and guilds showed different responses to habitat characteristics such as vegetation cover and human activities (plowing the soil, planting, watering and selective intervention at harvest crops). Alaruikka et al. (2002) in Finland confirmed the significant influence of the locality. In Slovakia, we noticed a very high species diversity of spiders in the researched garden, although the abundance was not so high. Selected microhabitats offered suitable and appropriate specific living conditions. One quarter of collected individuals were in the immature stage of development (pullus or subadults) identified at the genus level. Nevertheless, all together 74 species we confirmed there.

Urban areas encompass a wide range of ecosystems, include regions of high native biodiversity, and are inhabited by rare and threatened species. Public and private gardens often provide novel resources that might not otherwise exist in the urban landscape (Davies et al., 2009). Based on our research we confirmed the hypothesis the gardens create conditions and offer space for specific species little known from the natural environment. Surprisingly, we found the presence of four non-native spider species, or two soil mite species - Corynoppia kosarovi and Mesoplophora pulchra (Krumpálová et al., 2020b) in the investigated gardens. We agree with the works of Loram et al. (2008) and Edmondson et al. (2014) that urban gardens are a major component of green spaces in many countries; they are heterogeneous in structure, but despite their relatively small size they provide critical habitat resources and increase the connectivity of urban landscapes (Soanes et al., 2019). 
In our study, most of spider species we found in relatively small numbers. We obtained similar results in the research of soil mites in the garden - most oribatids occurred in very small amounts (Krumpálová et al., 2020b), probably due to habitat requirements of species and their trophic supply, as well as human activities in the garden. Horváth et al. (2014) concluded a high share of rare species (singletons) as a common phenomenon in spider assemblages. On the basis of the studies, no generalization is possible about rarity patterns. The highest number of singleton species was in the suburban zone in Denmark (Horváth et al., 2014); in Hungary Magura et al. (2010) confirmed in the urban habitat eight species and Alaruikka et al. (2002) in the rural habitat in Finland 17 species. The number of singleton species was high in urban forest fragments in all countries. This could be an effect of the matrix - the trees become a fragment in the urban setting, with extensive surrounding matrix areas, which influences the faunal composition of the fragments as well (Lövei et al., 2006).

The hypothesis that a higher diversity of plants will have a positive effect on higher diversity of spiders (in contrast of recreational garden) was not confirmed. In the two microhabitats in planted garden we found lower number of species as in recreational parts. This fact may be a result of high disturbance and seasonal human activities.

The increasing disturbance hypothesis suggests that species richness monotonously decreases as the disturbance increasing (Gray, 1989). Magura et al. (2010) summarised that in disturbed, thinned urban park with increased ground and air temperature contained several favourable microhabitats for open-habitat species. Habitat management that does not modify considerably the habitat structure but rather mimics natural processes could serve both the demands of humans and the maintenance of the diversity of habitat-specific species. We can confirm and document these findings. After the complete harvesting of crops and the removal of vegetation cover in the managed garden, we did not catch the spiders. Disruptions of area in this range cause the disappearance epigeic individuals for some time, even in conditions of private garden. Thomas and Jepson (1997) said the same conclusions many years ago - farming operations result in major habitat-scale disturbance for spiders. Harvesting, plowing, pesticide spraying and forest clearcutting are likely to affect most micro-habitats within a given habitat; and they are known to cause severe reductions in spider populations.

Braschler et al. (2020) assumed besides larger public green spaces such as parks, urban forests and greenways, domestic urban gardens in aggregate constitute a considerable share of the overall urban area. Habitat provided by public and private urban green space has an increased importance in supporting populations of animal and plant species. For example, urban green space could play an important role in mitigating insect declines. However, the few published studies surveying the ground-dwelling invertebrate biodiversity of urban domestic and community gardens, reported considerable numbers of individuals and species in various invertebrate groups if data of multiple gardens were combined (Braschler et al., 2020).

Taken together, a sample of private domestic urban gardens represents a wide range of habitat types, with various degrees of management intensity and a huge range of naturalness (abundance of native plant species, presence of wildlife friendly features such as dead wood or stone piles, extensive management of grassland, bushes and hedges). Thus, a sample of private domestic urban gardens offers niches for numerous species with very different requirements (Braschler et al., 2020). Recognizing the value of small spaces and unconventional habitats for native species, and the potential for creative conservation opportunities, opens up new avenues for managers in urban 
environments and will lead to better conservation outcomes. Our study suggests that private gardens (as part of the green infrastructure of an urban environment) increase diversity in terms of species richness and are important for regional diversity. Urban planners should consider the value of the biological mosaic of highly variable home gardens and upgrade their biodiversity.

\section{Conclusions}

The garden is a very important refuge of the urban environment, it is a significantly altered habitat, disturbed by man, yet it forms an interesting and diverse ecosystem. The presence of 99 taxa has been identified in the course of the research of private gardens' microhabitats in Slovakia. Taxonomic spectrum of families is dominated by Linyphiidae (25), followed by Lycosidae (20), Gnaphosidae (13), Agelenidae (8), Theridiidae (6), Hahnidae and Thomisidae (4 species on each), Pholcidae and Dysderidae (3 species on each) the remaining 11 families were represented by only one (two) species.

Different degree of disturbance and different microhabitat conditions (man-made) significantly affected the species diversity of coenoses and through PCA analysis we confirmed relatively large differences in the structure of araneocoenoses in studied microhabitats. The highest degree of disturbance was in the garden with crops (lowest values of diversity indices), so we confirmed the hypothesis that soil management will reduce the species diversity in garden.

The garden is also a refuge for many euryvalent and synanthropic species (e.g. Scytodes thoracica) and creates a potential space for the spread and acclimatization of non-native species (e.g. H. forskali, M. trilobatus, T. vindobonensis, or T. hasperi).

The results of this research, specifically the research of spiders in the private garden of a family house among various microhabitats, are unique and the first of its kind not only in Slovakia but also in Central Europe. We consider it important to continue research and monitoring of interesting populations of spiders in gardens.

Acknowledgements. We thank Mr. Pavol Purgat for help with field work and Mr. Rudolf Krumpál for language corrections. We would like to thank all the opponents for the professional assessment of the manuscript. We are grateful to the Slovak Grant Agency for the support of research and this work through the projects - VEGA - no. 1/0604/20 and KEGA - no. 019UKF-4/2021.

\section{REFERENCES}

[1] Alaruikka, D., Kotze, D. J., Matveinen, K., Niemelä, J. (2002): Carabid and spider assemblages along an urban to rural gradient in southern Finland. - Journal of Insect Conservation 6: 195-206. doi: 10.1023/A:1024432830064.

[2] Baranová, B., Manko, P., Jászay, T. (2015): Waste dumps as local biodiversity hotspots for soil macrofauna and ground beetles (Coeloeptera: Carabidae) in the agricultural landscape. - Ecological Engineering 8: 1-13. doi: 10.1016/j.ecoleng.2015.04.023.

[3] Braschler, B., Gilgado, J. D., Zwahlen, V., Rusterholz, H. P., Buchholz, S., Baur, B. (2020): Ground-dwelling invertebrate diversity in domestic gardens along a rural-urban gradient: Landscape characteristics are more important than garden characteristics. PLoS ONE 15. doi: 10.1371/journal.pone.0240061. 
[4] Buchar, J., Růžička, V. (2002): Catalogue of Spiders of the Czech Republic. - Peres Publishing Praha.

[5] Davies, Z. G., Fuller, R. A., Loram, A., Irvine, K. N., Sims, V., Gaston, K. J. (2009): A national scale inventory of resource provision for biodiversity within domestic gardens. Biological Conservation 142: 761-771. doi: 10.1016/j.biocon.2008.12.016.

[6] Edmondson, J. L., Davies, Z. G., Gaston, K. J., Leake, J. R. (2014): Urban cultivation in allotments maintains soil qualities adversely affected by conventional agriculture. Journal Applied Ecology 51: 880-889. doi:10.1111/1365-2664.12254.

[7] Gajdoš, P., Černecká, L., Šestáková, A. (2019): Pannonic salt marshes revealed six new spiders to Slovakia (Araneae: Gnaphosidae, Linyphiidae, Lycosidae, Theridiidae). Biológia 74: 53-64. doi: 10.2478/s11756-018-0145-z.

[8] Gray, J. S. (1989): Effects of environmental stress on species rich assemblages. Biological Journal of the Linnean Society 37: 19-32. doi: 10.1111/j.1095-8312.1989.tb02003.x.

[9] Hammer, Ø., Harper, D. A. T., Ryan, P. D. (2001): PAST: Paleontological Statistics Software Package for Education and Data Analysis. - Paleontologia Electronica 4: 1-9.

[10] Heimer, S., Nentwig, W. (1991): Spinnen Mitteleuropas. - Verlag Paul Parey, Berlin doi: 10.1002/MMND.19920390117.

[11] Horváth, R., Elek, Z., Lövei, G. (2014): Compositional changes in spider (Araneae) assemblages along an urbanisation gradient near a Danish town. - Bulletin of Insectology 67: 255-264.

[12] Krumpálová, Z., Štipčáková, L., Ondrejková, N. (2020a): Influence of garden's plants on soil mites (Acari, Oribatida) and spiders (Araneae). - In: Bryja, J., Kuras, T., Tuf, I. H., Tkadlec, E. (eds.) Abstract book of Zoological Days Conference. CAS, Brno.

[13] Krumpálová, Z., Štipčáková, L., Petrovičová, K., Luptáčik, P. (2020b): Influence of plants on soil mites (Acari, Oribatida) in gardens. - Acta Fytotechnica et Zootechnica 23: 94-101. doi: 10.15414/afz.2020.23.02.94-101.

[14] Loram, A., Warren, P. H., Gaston, K. J. (2008): Urban Domestic Gardens (XIV): The Characteristics of Gardens in Five Cities. - Environmental Management 42: 361-376. doi: 10.1007/s00267-008-9097-3.

[15] Lövei, G. L., Magura, T., Tóthméresz, B., Ködöböcz, V. (2006): The influence of matrix and edges on species richness patterns of ground beetles (Coleoptera: Carabidae) in habitat islands. - Global Ecology and Biogeography 15: 283-289. doi: 10.1111/j.14668238.2005.00221.x.

[16] Lowe, E. C., Threlfall, C. G., Wilder, S. M., Hochuli, D. F. (2017): Environmental drivers of spider community composition at multiple scales along an urban gradient. Biodiversity Conservation 27: 829-852. doi: 10.1007/s10531-017-1466-x.

[17] Magura, T., Horváth, R., Tóthméresz, B. (2010): Effects of urbanization on grounddwelling spiders in forest patches, in Hungary. - Landscape Ecology 25: 621-629. doi: 10.1007/s10980-009-9445-6.

[18] Miller, F. (1971): Araneida, - In: Daniel, M., Černý, V. (eds.) Klíč zvířeny ČSSR IV. ČSAV, Praha.

[19] Nentwig, W., Blick, T., Bosmans, R., Gloor, D., Hänggi, A., Kropf, Ch. (2020): Spiders of Europe, version 11/2020. - online at https//www.araneae.nmbe.ch. doi: 10.24436/1.

[20] Ondrejková, N., Purgat, P. (2019): Spiders as animal models for evaluation of garden disturbance. - In: Francisci, J., Zverková, K. (eds.) Proceedings of peer-reviewed papers of Student Scientific Conference, FNS Constantine the Philosopher University, Nitra, pp. 41-46.

[21] Porhajašová-Ivanič, J., Noskovič, J., Babošová, M. (2016): Coleoptera families fluctuation depending on the organic fertilizers application. - Acta fytotechnica et zootechnica 19: 150-156. doi: 10.1541/afz.2016.19.04.150-156.

[22] Post, W. M., Riechert, S. E. (1977): Initial Investigation into the Structure of Spider Communities. - Journal of Animal Ecology 46: 729-749. jstor org/stable/3637. 
[23] Purgat, P., Krumpálová, Z., Lelovicsová, S., Petrovičová, K. (2020): Spreading of spiders (Araneae) in the urban environment as an impact of human activities. - In: Fialová, J. (ed.) Public recreation and landscape protection - with sense hand in hand? Conference proceedings of peer-reviewed papers, Mendel University, Brno, pp. 430-434. ISBN (online) 978-80-7509-716-3.

[24] Růžička, V. (1987): Biodiagnostic evaluation of epigeic spider communities. - Ekologia 6: 346-357.

[25] Samu, F., Sunderland, K. D., Szinetár, C. (1999): Scale-Dependent Dispersal and Distribution Patterns of Spiders in Agricultural Systems: A Review. - The Journal of Arachnology 27: 325-332. jstor.org/stable/3706004.

[26] Soanes, K., Sievers, M., Chee, Y. E., Williams, N. S. G., Bhardwaj, M., Marshall, A. J., Parris, K. M. (2019): Correcting common misconceptions to inspire conservation action in urban environments. - Conservation Biology 33: 300-306. doi: 10.1111/cobi.13193.

[27] StatSoft Inc. (2004): Statistica (Data analysis Software System), version 7.

[28] Šestáková, A., Suvák, M., Krajčovičová, K., Kaňuchová, A., Christophoryová, J. (2017): Arachnids from the greenhouses of the Botanical Garden of the PJ Safárik University in Košice, Slovakia (Arachnida: Araneae, Opiliones, Palpigradi, Pseudoscorpiones). Arachnologische Mitteilungen 53: 19-28. doi: 10.5431/aramit5304.

[29] Tajthi, B., Horváth, R., Mizser, Sz., Nagy, D. D., Tóthmérész, B. (2017): Spider assemblages in floodplain forests along an urbanization gradient. - Community Ecology 18: 311-318. doi: 10.1556/168.2017.18.3.10.

[30] Ter Braak, C. J. F., Šmilauer, P. (2012): Canoco reference manual and user's guide: software for ordination, version 5.0. - Ithaca USA, Microcomputer Power.

[31] Thomas, C. F. G., Jepson, P. C. (1997): Field-scale effects of farming practices on linyphiid spider populations in grass and cereals. - Entomologia Experimentalis et Applicata 84(1): 59-69. doi: 10.1046/j.1570-7458.1997.00198.x.

[32] Tresch, S., Frey, D., Bayon, R. C. L., Mäder, P., Stehle, B., Fliessbach, A., Moretti, M. (2019): Direct and indirect effects of urban gardening on aboveground and belowground diversity influencing soil multifunctionality. - Scientific Reports 9: 9769. doi: 10.1038/s41598-019-46024-y.

[33] World Spider Catalog (2020): World Spider Catalog, version 21.5. - Natural History Museum Bern, online at http://wsc.nmbe.ch. doi: 10.24436/2.

[34] Les araignées de Belgique et de France: www.arachno.piwigo.com 